\title{
Effect of parachlorophenylalanine, a specific 5-HT depleter on fluoxetine and d-fenfluramine induced penile erections in rats
}

\author{
More Kanhaiah*1, Vandana M Thorat ${ }^{2}$, Anjali R Shinde ${ }^{3}$, Santosh G Gursale ${ }^{4}$ \\ ${ }^{1}$ Assistant Professor, Dept of Pharmacology, Travancore Medical College, Medicity, Kollam, Kerala, India, \\ ${ }^{2}$ Professor, Dept of Pharmacology, Krishna Institute of Medical Sciences University Karad, Maharashtra, India, \\ ${ }^{3}$ Assistant Professor, Dept of Pharmacology, PIMS, Islampur, Maharashtra, ${ }^{4}$ Professor, Dept of Pharmacology, IMSR \\ Medical College, Mayani, Maharashtra, India
}

Address for Correspondence: Dr. More Kanhaiah, Travancore Medical College, Medicity, Kollam, Kerala.

\begin{abstract}
Objective: To determine whether fluoxetine (FLU) induces penile erection (PE) in rats either indirectly via its 5-HT neuronal reuptake inhibiting activity or directly by stimulating the 5- $\mathrm{HT}_{2 \mathrm{c}}$ receptors in the brain. Method: The effect of pre-treatment with para-Chlorophenylalanine (PCPA) on fluoxetine and d-fenfluramine (d-FEN) induced PEs (Penile erections) was studied in albino rats. Results: FLU $(10 \mathrm{mg} / \mathrm{kg})$ and d-FEN $(2.5 \mathrm{mg} / \mathrm{kg})$ treated groups exhibited a significant increase in number of PEs as compared to their respective control (DW treated) groups. Pre-treatment with PCPA (100mg/kg/day) had no significant effect on the PEs induced by FLU $(10 \mathrm{mg} / \mathrm{kg})$ but did significantly decrease the PEs induced by d-FEN $(2.5 \mathrm{mg} / \mathrm{kg})$. Conclusion: Our results indicate that pre-treatment with selective 5-HT depleter PCPA $(100 \mathrm{mg} / \mathrm{kg} /$ day) significantly decreased PEs induced by d-FEN $(2.5 \mathrm{mg} / \mathrm{kg})$ but had no significant effect on the number of PEs induced by FLU $(10 \mathrm{mg} / \mathrm{kg})$. This indicates that the PE inducing effect of FLU is probably due to the stimulation of $5 \mathrm{HT}_{2 \mathrm{C}}$ receptors.
\end{abstract}

Key words: Fluoxetine (FLU), d-Fenfluramine (d-FEN), Parachlorophenylalanine (PCPA), Penile Erections (PEs), Distilled water (DW), Intraperitoneal injection (ip), Metachlorophenylpiperazine (mCPP), 5-Hydroxytriptamine (5-HT).

\section{Introduction}

Penile erections (PEs) induced by metaChlorophenylpiperazine (mCPP) and the indirectly acting agonists (E.g. fluoxetine and fenfluramine) were suggested to be $5 \mathrm{HT}_{1 \mathrm{~B}}$ receptor mediated. However following discovery of $5 \mathrm{HT}_{1 \mathrm{C}}$ receptor, mCPP a drug considered to be $5 \mathrm{HT}_{1 \mathrm{~B}}$ receptor selective agonist was found to bind more strongly to $5 \mathrm{HT}_{1 \mathrm{C}}$ receptors [1]. Later the $5 \mathrm{HT}_{1 \mathrm{C}}$ receptor was included in $5 \mathrm{HT}_{2}$ receptor family and redesigned as $5 \mathrm{HT}_{2 \mathrm{C}}$ receptors (2). $5 \mathrm{HT}_{2 \mathrm{C}}$ receptor activation is involved in induction of PEs [2, 3, $4]$.

Penile erections (PEs) can be induced in rats by serotonergic (5-HT) releasing compounds like fenfluramine and SSRIs (Selective Serotonin Reuptake Inhibitors) like fluoxetine. Direct or indirect activation

Manuscript received: $14^{\text {th }}$ Sept 2015

Reviewed: $24^{\text {th }}$ Sept 2015

Author Corrected: $10^{\text {th }}$ Oct 2015

Accepted for Publication: $16^{\text {th }}$ Oct 2015 of central $5 \mathrm{HT}_{2 \mathrm{C}}$ receptors induces penile erections in rats $[5,1,2]$. Fluoxetine induces penile erections in rats either indirectly via its 5-HT reuptake inhibiting activity or directly by stimulating the $5 \mathrm{HT}_{2 \mathrm{C}}$ receptors $[5,6]$. Further in the present study we have determined that fluoxetine induces penile erections directly by stimulating central $5 \mathrm{HT}_{2 \mathrm{C}}$ receptors.

\section{Materials and Methods}

Animals: Albino male wistar rats weighing 100-180 grams, bred in Central Animal House of the Institute, were used. The animals were housed under standard conditions, maintained on a 12 hour light/dark cycle and had free access to food and water up to the time of experimentation. The animals were brought to the department and kept in a noiseless diffusely illuminated laboratory, at least $1 \mathrm{hr}$ before the experiments for acclimatization to the laboratory environment. Each group consisted of 10 animals. Each animal was used only once. All observations were made between 10:00 
and 17:00 $\mathrm{Hrs}$ at $27^{\circ}-30^{\circ} \mathrm{C}$. Observations were made blind with respect to the treatments used. The experimental protocols were approved by the Institutional Animal Ethics Committee and conducted according to the Indian National Science Academy Guidelines for the use and care of experimental animals.

Drugs: Drugs used were fluoxetine hydrochloride (Sun Pharmaceuticals), d-fenfluramine hydrochloride (Wockhardt) and d-parachlorophenylalanine methyl ester hydrochloride (Sigma). All drug solutions were prepared immediately before use and were injected intraperitoneally. The volume of injection was $5 \mathrm{ml} / \mathrm{kg}$ body weight for PCPA and $2 \mathrm{ml} / \mathrm{kg}$ body weight for the remaining drugs. Doses refer to the forms mentioned and were selected on the basis of previous studies conducted in our laboratory and those reported in literature.

PCPA on fluoxetine and d-fenfenfluramine (d-FEN) induced penile erections (PEs) in male rats: The methodology followed was similar to that of Berendsen

\section{Results}

In preliminary experiments, it was observed that 2.5 to $20 \mathrm{mg} / \mathrm{kg}$ FLU produced neither gross behavioural changes nor induced stereotyped behaviour (SB) of oral movement variety (OMV) or any feature of the 5- $\mathrm{HT}_{1 \mathrm{~A}}$ and $5-\mathrm{HT}_{2 \mathrm{~A}}$ receptor mediated behavioural syndrome in the rats. However, male rats given 5, 10 and $20 \mathrm{mg} / \mathrm{kg}$ FLU exhibited the 5-HT $2 \mathrm{C}$ receptor mediated PEs. As FLU at $40 \mathrm{mg} / \mathrm{kg}$ dose had produced ataxia, motor incoordination and muscular hypotonia, for subsequent studies it was therefore used in the dose range of 2.5 to $20 \mathrm{mg} / \mathrm{kg}$.

Effect of PCPA pre-treatment on FLU and d-FEN induced PEs in male rats: The results are given in Table 1. FLU $(10 \mathrm{mg} / \mathrm{kg})$ and d- FEN (2.5 mg/kg) treated groups pre-treated with DW (5 ml/kg ip daily for 4 days) exhibited a significant increase in the number of PEs as compared to their respective control DW ( $2 \mathrm{ml} / \mathrm{kg}$ ip) treated group pretreated with DW (5 ml/kg ip daily for 4 days).

Pre-treatment with PCPA (100 mg/kg/day for 4 days) had no significant effect on the number of PEs induced by 10 $\mathrm{mg} / \mathrm{kg}$ FLU. However, pre-treatment with PCPA (100 mg/kg/day for 4 days) did significantly decrease the number of PEs induced by $2.5 \mathrm{mg} / \mathrm{kg}$ d- FEN.

Table 1: Effect of PCPA pre-treatment on FLU and d- FEN induced PEs in male rats.

\begin{tabular}{|l|c|}
\hline Treatment dose $\mathbf{~ m g / k g}$ & $\begin{array}{c}\text { Number of PEs } \\
\text { Mean } \pm \text { S.E.M. }\end{array}$ \\
\hline 1. DW + DW & $0.3 \pm 0.15$ \\
2. DW + FLU 10 & $3.6 \pm 0.16^{\mathrm{a}}$ \\
3. PCPA 400 + FLU 10 & $3.7 \pm 0.15$ \\
\hline 1. DW + DW & \\
2. DW + d- FEN 2.5 & $0.4 \pm 0.16$ \\
3. PCPA 400 + d- FEN 2.5 & $3.2 \pm 0.13^{\mathrm{a}}$ \\
\hline
\end{tabular}


${ }^{a} \mathrm{P}<0.001$ as compared by the Student's unpaired t-test to the respective distilled water (DW, $2 \mathrm{ml} / \mathrm{kg}$ ip) treated control group pre-treated with DW ( $5 \mathrm{ml} / \mathrm{kg}$ ip daily for 4 days).

${ }^{\mathrm{b}} \mathrm{P}<0.001$ as compared to the d- FEN ( $2.5 \mathrm{mg} / \mathrm{kg}$ ip) treated group pre-treated with DW ( $5 \mathrm{ml} / \mathrm{kg}$ ip daily for 4 days).

\section{Discussion}

The effect of pre-treatment with the selective 5-HT depleter PCPA was investigated on FLU induced PEs and d-FEN induced PEs. The study was conducted to determine whether FLU induces the PEs by stimulating the $5-\mathrm{HT}_{2 \mathrm{C}}$ receptors either directly or indirectly via the accumulated 5-HT in the synaptic cleft resulting due to blockade of 5-HT reuptake.

Penile erections (PEs) result from activation of $5-\mathrm{HT}_{2 \mathrm{C}}$ receptors $[6,1,3]$. FLU and d- FEN are reported to induce PEs [5]. The mechanism whereby FLU, fenfluramine and d- FEN induce PEs is explained as follows.

FLU at 5, 10 and $20 \mathrm{mg} / \mathrm{kg}$ doses, by blocking the neuronal reuptake of 5-HT, causes accumulation of 5HT in the synaptic cleft with resultant stimulation of the 5- $\mathrm{HT}_{2 \mathrm{C}}$ receptors and occurrence of PEs. Alternatively, since FLU has moderate affinity for the $5-\mathrm{HT}_{2 \mathrm{C}}$ receptors [6], it might be inducing the PEs by directly stimulating the $5-\mathrm{HT}_{2 \mathrm{C}}$ receptors.

Fenfluramine and its d-isomer, d-FEN, like 5-HT and para-Chloroamphetamine (PCA), are taken up into the 5-HTergic (serotonergic) neurons by the same uptake carrier protein SERT [7]. After entering into the 5HTergic neurons fenfluramine and d-FEN cause a brisk release of 5-HT from the 5-HTergic neurons with resultant stimulation of all the 5-HT receptor subtypes by the released 5-HT [7 ]. PEs induced by $5-\mathrm{HT}_{2 \mathrm{C}}$ receptor activation are functionally inhibited by the activation of $5-\mathrm{HT}_{1 \mathrm{~A}}$ and $5-\mathrm{HT}_{2 \mathrm{~A}}$ receptors. They are evident only when the $5-\mathrm{HT}_{1 \mathrm{~A}}$ and $5-\mathrm{HT}_{2 \mathrm{~A}}$ receptor mediated behaviors are blocked by the $5-\mathrm{HT}_{1 \mathrm{~A}}$ and 5$\mathrm{HT}_{2 \mathrm{~A}}$ receptor antagonists respectively [8,5,1]. PEs are therefore induced only by smaller doses of fenfluramine (2.2 and $4.6 \mathrm{mg} / \mathrm{kg}$ ) (5) which do not induce the $5-\mathrm{HT}_{1 \mathrm{~A}}$ and $5-\mathrm{HT}_{2 \mathrm{~A}}$ receptor mediated behaviours that occur following administration of higher doses of fenfluramine $[9,10]$.

In preliminary studies it was observed that treatment with $1.25 \mathrm{mg} / \mathrm{kg} \mathrm{d}$-FEN did not induce PEs. However, treatment with $2.5 \mathrm{mg} / \mathrm{kg} \mathrm{d}$-FEN induced only PEs whereas treatment with 5,10 and $15 \mathrm{mg} / \mathrm{kg} \mathrm{d}-\mathrm{FEN}$ induced only $5-\mathrm{HT}_{1 \mathrm{~A}}$ and $5-\mathrm{HT}_{2 \mathrm{~A}}$ receptor mediated behaviors. For further study d-FEN was therefore used in the dose of $2.5 \mathrm{mg} / \mathrm{kg}$.

The anti-immobility effect of FLU in the rat forced swimming test (FST), which is dependent on FLU's 5HT neuronal reuptake blocking activity and consequent accumulation of 5-HT in the synaptic cleft, was reported to be antagonized by PCPA pre-treatment [11]. The antagonism of the anti-immobility effect of FLU in the rat FST by PCPA pre-treatment was explained by Page et al [11] as follows. PCPA, by selectively inhibiting tryptophan hydroxylase, the rate limiting enzyme in 5-HT biosynthesis, decreases the intraneuronal stores of 5-HT [12]. Consequently less amount of 5-HT is released from the 5-HTergic neurons resulting in a decrease in the concentration of 5-HT in the synaptic cleft and less amount of 5-HT being available for FLU to block the reuptake. Less amount of 5-HT will therefore accumulate in the synaptic cleft due to FLU's 5-HT neuronal reuptake blocking activity. Consequently the various 5-HT receptor subtypes involved in the anti-immobility effect of FLU will be stimulated to a lesser extent with resultant antagonism of FLU's anti-immobility effect. We studied the effect of pre-treatment with PCPA on FLU $(10 \mathrm{mg} / \mathrm{kg})$ induced PEs to determine whether FLU elicits the PEs indirectly via its 5-HT neuronal reuptake blocking activity and subsequent stimulation of the $5-\mathrm{HT}_{2 \mathrm{C}}$ receptors by the accumulated 5-HT in the synaptic cleft or by direct stimulation of the $5-\mathrm{HT}_{2 \mathrm{C}}$ receptors.

Pre-treatment with PCPA, by depleting brain 5-HT [12], makes less amount of 5-HT available for release by fenfluramine and thus antagonizes the fenfluramineinduced $5-\mathrm{HT}_{1 \mathrm{~A}}$ and $5-\mathrm{HT}_{2 \mathrm{~A}}$ receptor mediated behavioral syndrome $[9,10]$. We studied the effect of pre-treatment with PCPA on d-FEN $(2.5 \mathrm{mg} / \mathrm{kg})$ induced PEs to determine whether PCPA pre-treatment decreases the number of PEs induced by $2.5 \mathrm{mg} / \mathrm{kg} \mathrm{d}$ FEN.

In the present study pre-treatment with PCPA (100 $\mathrm{mg} / \mathrm{kg} / \mathrm{day}$ for 4 days) had no significant effect on the number of PEs induced by $10 \mathrm{mg} / \mathrm{kg}$ FLU but did 
significantly decrease the number of PEs induced by 2.5 $\mathrm{mg} / \mathrm{kg}$ d-FEN. Since PCPA pre-treatment had antagonized the effect of d-FEN it indicates that the dosing schedule of PCPA had caused significant depletion of brain 5-HT. PCPA pre-treatment, despite causing significant depletion of brain 5-HT, however, failed to decrease the number of PEs induced by 10 $\mathrm{mg} / \mathrm{kg}$ FLU. This indicates that the PE inducing effect of FLU is not dependent on the availability of brain 5HT.

The anti-immobility effect of FLU in the rat FST is dependent on the availability of brain 5-HT and is antagonized following depletion of brain 5-HT by PCPA pre-treatment [11]. However, in our study the PE inducing effect of $10 \mathrm{mg} / \mathrm{kg}$ FLU was not antagonized following depletion of brain 5-HT by PCPA pretreatment. Our finding thus indicates that the PE inducing effect of $10 \mathrm{mg} / \mathrm{kg}$ FLU is not dependent on the availability of brain 5-HT and that FLU induces the PEs by a direct agonistic action on the $5-\mathrm{HT}_{2 \mathrm{C}}$ receptors.

Our finding and the conclusion derived thereof that FLU induces the PEs by directly stimulating the $5-\mathrm{HT}_{2 \mathrm{C}}$ receptors is in agreement with the reports of Zhang et al [13] and Chen et al [14]. These workers have reported that FLU, like nanomolar concentrations of 5-HT, induces glycogenolysis and an increase in free cytosolic $\mathrm{Ca}^{2+}$ concentration in cultured astrocytes and glial cells by directly stimulating the $5-\mathrm{HT}_{2 \mathrm{C}}$ receptors.

\section{Funding: Nil \\ Conflict of interest: None. \\ Permission of IRB: Yes}

\section{References}

1. Berendsen HH, Jenck F, Broekkamp CL. Involvement of 5-HT1C-receptors in drug-induced penile erections in rats. Psychopharmacology (Berl). 1990;101(1):57-61.

2.

MartinGR, HumphreyPPReceptors for 5hydroxytrypta mine: current perspectives on classification and nomenc lature. Neuropharmacology. 1994 Mar-Apr;33(34):261-73.

3. Millan MJ, Peglion JL, Lavielle G, PerrinMonneyron S 5-HT2C receptors mediate penile erections in rats: actions of novel and selective agonists and antagonists. Eur J Pharmacol. 1997 Apr 23;325(1):9-12.

4. Kimura Y, Naitou Y, Wanibuchi F, Yamaguchi T. 5$\mathrm{HT}(2 \mathrm{C})$ receptor activation is a common mechanism on proerectile effects of apomorphine, oxytocin and melanotan-II in rats. Eur J Pharmacol. 2008 Jul 28;589(1-3):157-62. doi: 10.1016/j.ejphar.2008.05.022. Epub 2008 May 24.

5. Berendsen HH, Broekkamp CL. Drug-induced penile erections in rats: indications of serotonin1B receptor mediation. Eur J Pharmacol. 1987 Mar 31;135(3):27987.

6. Jenck F, Moreau JL, Mutel V, Martin JR, Haefely WE. Evidence for a role of 5-HT1C receptors in the antiserotonergic properties of some antidepressant drugs. Eur J Pharmacol. 1993 Feb 9;231(2):223-9.

7. Cooper JR, Bloom FE, Roth RH. The Biochemical basis of Neuropharmacology. 8th ed. New York: Oxford University Press; 2003. p. 271-320.

8. Wanibuchi F, Usuda S. Synergistic effects between D-1 and D-2 dopamine antagonists on catalepsy in rats. Psychopharmacology (Berl). 1990;102(3):339-42.

9. Trulson ME, Jacobs BL. Behavioral evidence for the rapid release of CNS serotonin by PCA and fenfluramine. Eur J Pharmacol. 1976 Mar;36(1):149-54.

10. Thorat VM, Gaonkar RK, Bhosale KB, Balsara JJ. Effects of dexfenfluramine on dopamine dependent behaviours in rats. Indian J Physiol Pharmacol. 2005 Jan;49(1): 39-48.

11. Page $\mathrm{ME}^{1}$, Detke MJ, Dalvi A, Kirby LG, Lucki I. Serotonergic mediation of the effects of fluoxetine, but not desipramine, in the rat forced swimming test. Psychopharmacology (Berl). 1999 Nov;147(2):162-7.

12. Koe BK, Weissman A. p-Chlorophenylalanine: a specific depletor of brain serotonin. J Pharmacol Exp Ther. 1966 Dec;154(3):499-516.

13. Zhang X, Peng L, Chen Y, Hertz L. Stimulation of glycogenolysis in astrocytes by fluoxetine, an antidepressant acting like 5-HT. Neuroreport. 1993 Sep 10;4(11):1235-8. 
14. Chen Y, Peng L, Zhang X, Stolzenburg JU, Hertz L. Further evidence that fluoxetine interacts with a 5-
HT2C receptor in glial cells. Brain Res Bull. 1995;38(2):153-9.

\section{How to cite this article?}

More Kanhaiah, Vandana M Thorat, Anjali R Shinde, Santosh G Gursale. Effect of parachlorophenylalanine, a specific 5-HT depleter on fluoxetine and d-fenfluramine induced penile erections in rats. Int J Med Res Rev 2015;3(9):959-963. doi: 10.17511/ijmrr.2015.i9.178. 